\title{
Locke, God, and Materialism
}

Stewart Duncan

Forthcoming in Oxford Studies in Early Modern Philosophy

\section{INTRODUCTION}

Early modern philosophers discussed several versions of materialism. One distinction among them is that of scope. Should one be a materialist about animal minds, human minds, the whole of nature, or God? Hobbes eventually said 'yes' to all four questions, and Spinoza seemed to several of his readers to have done the same. Locke, however, gave different answers to the different questions. Though there is some debate about these matters, it appears that he thought materialism about God was mistaken, was agnostic about whether human minds were material, and was inclined to think that animal minds were material. ${ }^{1}$ In giving those answers, Locke famously suggested the possibility that God might have 'superadded' thought to the matter of our bodies, giving us the power of thought without immaterial thinking minds. He thus opened up the possibility of materialism about human minds, without adopting the sort of general materialist metaphysics that Hobbes, for example, had proposed.

This paper investigates Locke's views about materialism, by looking at the discussion in Essay IV.x. There Locke—after giving a cosmological argument for the existence of Godargues that God could not be material, and that matter alone could never produce thought. ${ }^{2}$ In

\footnotetext{
${ }^{1}$ On Locke on animals' minds, see Lisa Downing, 'Locke's Choice Between Materialism and Dualism' ['Locke's Choice'], in Paul Lodge and Tom Stoneham (ed.), Locke and Leibniz on Substance (New York: Routledge, 2015), 128-45; Nicholas Jolley, Locke's Touchy Subjects (Oxford: Oxford University Press, 2015), 33-49; and Kathleen Squadrito, 'Thoughtful Brutes: The Ascription of Mental Predicates to Animals in Locke's Essay', Diálogos 58 (1991), 63-73. ${ }^{2}$ I focus on the Essay. This focus includes concentrating on the sorts of views about God that Locke presents and argues for in the Essay, views about God that one can arrive at in philosophy, independently of revelation.
} 
discussing the chapter, I pay particular attention to some comparisons between Locke's position and those of two other seventeenth-century philosophers, René Descartes and Ralph Cudworth. Locke barely mentions Descartes's name in the Essay, but frequently engages with Cartesian ideas there. ${ }^{3}$ Essay IV.x is no exception; Locke's thought in the chapter has some Cartesian aspects, even as he criticizes Descartes. Meanwhile, Locke's knowledge of Cudworth's True Intellectual System, and its apparent connections to the discussion of IV.x, are well known, and I discuss some of those connections below. ${ }^{4}$

Making use of those comparisons, I argue for two main claims. The first is that the important argument of Essay IV.x.10 is fundamentally an argument about the causation of perfections. Indeed, Locke gives multiple such arguments in the chapter. My second main claim is that my proposed reading of IV.x is not merely consistent with what Locke says elsewhere about superaddition, but also provides reasons to favor a particular understanding of what superaddition is. ${ }^{5}$

\footnotetext{
${ }^{3}$ Unsurprisingly, Locke owned several of Descartes' books. John Harrison and Peter Laslett, The Library of John Locke, second edition (Oxford: Clarendon Press, 1971), \#601a-608, p.101; \#2451, p.218.

${ }^{4}$ On Locke and Cudworth, see Michael Ayers, Locke (London: Routledge, 1991), 2: 169-83, though at points below I disagree with the details of Ayers's reading. Locke owned a copy of the True Intellectual System (The Library of John Locke, \#896, p.119). Ayers, Locke, 2: 314following W. von Leyden, 'Locke and Nicole', Sophia 16 (1948), 41-55-also notes a possible connection to Pierre Nicole's Discours sur l'existence de Dieu, which Locke had translated (Pierre Nicole, John Locke as Translator: Three of the Essais of Pierre Nicole in French and English, edited by Jean S. Yolton [Oxford: Voltaire Foundation, 2000]). However, not only is Nicole's discussion considerably less detailed than Cudworth's, it also lacks key elements that are prominent in the True Intellectual System and Essay IV.x, including the emphasis on creation ex nihilo and getting something from nothing.

${ }^{5}$ Space does not permit consideration of a further question that has seen recent discussion (Downing, 'Locke's Choice'; Jolley, Locke's Touchy Subjects), of whether Locke in some sense inclined towards materialism, despite his official agnosticism.
} 


\section{THE EARLY SECTIONS OF ESSAY IV.x}

I want to use Essay IV.x to talk about Locke's approach to materialism, but that is probably not what the chapter is best known for. Its most famous topic is Locke's argument for the existence of God, which he presents in the first six sections. Locke argues that each person has intuitive knowledge (the highest sort) of their own existence, and can have consequent demonstrative knowledge (the second highest sort) of the existence of an eternal being.

That basic argument for God's existence is a sort of cosmological argument. Given our knowledge of our own existence, and the principle (of which we are supposed to have intuitive knowledge) that 'bare nothing can no more produce any real Being, than it can be equal to two right Angles' ( $E$ IV.x.3), Locke concludes that 'from Eternity there has been something' ( $E$ IV.x.3), which he calls an 'eternal Being' (E Iv.x.4). It is well known that there is a gap, or at least a very significant unstated premise, in Locke's argument. Perhaps Locke's premises allow him to establish that at any time in the past, there has been some being or other. Locke concludes more strongly, however, that there is one being that has existed at all past times. ${ }^{6}$ As we will see, Locke seems to think that everyone agrees that there is an eternal being. Even atheists think this - they just think the eternal being is matter. Perhaps this helps explain the weakness of Locke's initial argument - the existence of an eternal being is just not, he thinks, a contentious claim that one needs to worry about establishing. The real issue is what that eternal being is like. That, indeed, is the focus of most of Locke's chapter.

\footnotetext{
${ }^{6}$ Locke talks about the being existing 'from Eternity' ( $E$ IV.x.3), suggesting an 'eternal' being that exists at all times, rather than a timeless one. For some discussion of the noted problem with the argument, see Marcy Lascano, 'Locke's Philosophy of Religion'. in Matthew Stuart (ed.), A Companion to Locke (Chichester: Blackwell, 2016), 467-85, at 471-3; and Jonathan Bennett, 'God and Matter in Locke: An Exposition of Essay IV.10' ['God and Matter'], in Eileen O'Neill and Christia Mercer (ed.), Early Modern Philosophy: Mind, Matter, and Metaphysics (Oxford: Oxford University Press, 2005), 161-182, at 163-4.
} 
Locke's cosmological argument manages to be noticeably Cartesian while departing from Descartes' own cosmological argument. Locke and Descartes both proceed by observing something we know of, and then looking for a causal explanation of that thing. In Descartes' case, that thing is 'the idea of a supremely perfect and infinite being' (AT 7: 46). Locke begins however from each individual's knowledge of their own existence: 'it is beyond question, that man has a clear perception of his own being; he knows certainly, that he exists, and that he is something' (E IV.x.2). Though Descartes was not the only philosopher ever to think about our knowledge of our own existence, there does appear to be a notable echo of the cogito here. ${ }^{7}$

Nevertheless, there is also notable anti-Cartesian material early in the chapter. Section 7 criticizes the practical utility of arguments for the existence of God that depend crucially upon an idea of God. Locke does not consider the quality of the arguments themselves. But he does say that

it is an ill way of establishing this truth, and silencing atheists, to lay the whole stress of so important a point, as this, upon that sole foundation: and take some men's having that idea of God in their minds, (for 'tis evident, some men have none, and some worse than none, and the most very different,) for the only proof of a Deity ( $E$ IV.x.7).

This seems to be directed at Descartes. ${ }^{8}$ The claim is not that it's bad to give an argument for the existence of God that begins from the idea of God, but that it's ineffective to rely only on such

\footnotetext{
${ }^{7}$ One might compare Locke's argument to the discussion in the Third Meditation of 'whether I possess some power enabling me to bring it about that I who now exist will still exist a little while from now' (AT 7: 49, CSM 2: 33). That, like Locke's argument, starts from the existence of the individual arguing. But unlike Locke's argument, it proceeds by thinking about the power of existing in the future, rather than what (in the past) explains my present existence.

${ }^{8}$ One might suggest that Locke's criticism also applies to Cudworth, who gives at one point a cosmological argument that focuses on the explanation of the existence of the idea of God (TIS 766-7). However, Cudworth seems also to be concerned there with the causal explanation of understanding more generally, and elsewhere endorses a more general version of the
} 
arguments if the goal is to confute atheists. Descartes, with his two arguments from the idea of God, does just that. ${ }^{9}$

Locke's argument for the existence of God appears late in the Essay. In book I, Locke had rejected the claim that religious knowledge was innate. In book IV, he was finally in a position to give his own account of religious knowledge, including knowledge of the existence of God. That placement of the argument for the existence of God is in contrast to Descartes' procedure. Descartes gave arguments for the existence of God as part of first philosophy, in the Meditations and early in the Principles. For Descartes, one ought, if proceeding systematically, to start by proving God's existence and move forward from there.

That is not to say that Locke's Essay before IV.x is a purely secular work, making no reference to God. Indeed, quite the opposite seems to be true. ${ }^{10}$ Locke appears to rely on the existence of a providential God who designed the world when making various arguments, from book 1 onwards. ${ }^{11}$ One might suggest then that Locke is proving in Essay IV.x what he earlier

cosmological argument (see for example TIS 727). The near-constant focus on arguments from the idea of God that we see in Descartes's work seems not to be present in Cudworth's.

${ }^{9}$ Descartes does sometimes argue in a way that seems less focused on the idea of God. See the discussion referred to in note 7 above. See also proposition III in the geometrical presentation at the end of the Second Replies (AT 7: 168-9). However, these arguments are much less prominent than those involving the idea of God. Moreover, the argument in the Second Replies still appears - at least in the proposition itself if not in the following discussion - to involve our possession of the idea of God.

${ }^{10}$ Several commentators have argued that religious commitments are fundamental to Locke's views in the Two Treatises. See John Dunn, The Political Thought of John Locke (Cambridge: Cambridge University Press, 1969); Jeremy Waldron, God, Locke, and Equality (Cambridge: Cambridge University Press, 2002); and P.E. Sigmund, 'Jeremy Waldron and the Religious Turn in Locke Scholarship', Review of Politics 67 (2005), 407-18. On the Essay, see Richard Ashcraft, 'Faith and Knowledge in Locke's Philosophy', in John Yolton (ed.), John Locke: Problems and Perspectives (Cambridge: Cambridge University Press, 1969), 194-223 and Ayers, Locke, 1: 123-4.

${ }^{11}$ Here are several examples, just from book II: the argument about whether the mind is always thinking relies on a belief about what God would not do, which is grounded in a view about the wisdom of God ( $E$ II.i.15); the argument of II.ii.3 relies on a claim about 'the Wisdom and Power of the Maker'; the discussion of pain in II.vii.4 notes a 'new occasion of admiring the 
relied upon. It is not clear, however, that Locke could do that, or that he tries to. Even if all the arguments of Essay IV.x work, they show the existence of God, and something about his attributes. Locke does not try to prove claims about God's wise and providential design of the world.

One further question about the early sections of Essay IV.x is how much Locke thinks he has established in them. Clearly he thinks he has shown, by the argument he reiterates at the end of IV.x.7, that there is a first cause, which is an eternal being. This knowledge is demonstrative, and thus of a high level of certainty: 'we more certainly know that there is a GOD, than that there is any thing else without us' ( $E$ IV.x.6). But how much are we supposed to know, at this point, about what God is like? On the one hand, Locke has argued that God is 'the most powerful' being ( $E$ IV.x.4) and that (because we have perception and knowledge) God must be a 'knowing intelligent Being' (E IV.x.5). ${ }^{12}$ On the other, as we will see, he begins soon afterwards to defend his view against the suggestion that the first cause is actually incogitative. So perhaps we should say, Locke believes at this point that he has shown that God is a thinking being, but recognizes that this position is not (yet) beyond criticism.

Wisdom and Goodness of our Maker'; the 'proper Functions' of the sense organ considered later in the section provide another example, for they are the functions for which it was intended and designed by God; II.xxi.48 on determination and freedom has an argument 'else he would be under the determination of some other than himself' that appears to rely on the view that God would not have placed us in such a situation (see II.xxi.53 and II.xxi.65); and II.xxiii.12 remarks on what the 'infinite, wise Contriver of us' has done in designing our senses and faculties.

${ }^{12}$ In those arguments Locke relies on two principles: the explicit one that if a being 'had its Being and beginning from another' ( $E$ IV.x.4), it must also get its powers from that earlier being; and the implicit one that the earlier being must itself in some way possess those powers. Locke also says in section 5 that that senseless matter cannot put sense, perception, and knowledge into itself. There is some question of whether the argument in section 5 merely relies on the two principles I have stated, or also offers extra considerations about the causation of thought. See Matthew Stuart, Locke's Metaphysics (Oxford: Clarendon, 2013), 251-2; and Bennett, 'God and Matter', 165-6. 


\section{AGAINST AN INCOGITATIVE FIRST CAUSE}

\subsection{The Overall Argument of IV.x.9-10}

Essay IV.x.9 tells us there are two sorts of beings in the world 'that Man knows or conceives': incogitative beings, and cogitative or thinking ones. Here Locke presumes that the incogitative beings are material, but not that the cogitative ones are immaterial. ${ }^{13} \mathrm{He}$ then argues, principally in section 10 , that the eternal being must be a cogitative being. Ignoring the details for a moment, this is an unsurprising consequence of earlier arguments. If God is the most knowing being, as Locke took himself to have shown by section 6 , then God must in some way be thinking. If we grant Locke further that there are only two sorts of beings we know of - the cogitative ones and the incogitative material ones - then God will be in the former category.

If we take things this way, then the main task of IV.x.9-10, indeed 9-12, is to answer the question, could the first cause have been an incogitative material being? Locke's answer is a firm 'no'.

Locke's framing here is, I note, rather similar to a way in which Ralph Cudworth had explained the debate between atheists and theists, with both accepting that something has existed from eternity, but disagreeing about what that is:

since Something certainly Existed of It self from Eternity, but other things were Made, and had a Beginning, (which therefore must needs derive their being from that which Existed of It self Unmade,) here is the State of the Controversie betwixt Theists and Atheists, Whether that which Existed of It self from all Eternity, and was the Cause of all other things, were a Perfect Being and God, or the most Imperfect of all things whatsoever, Inanimate and Sensless matter (TIS 727).

\footnotetext{
${ }^{13}$ Compare $E$ II.xxiii.15, where Locke contrasts material substances with immaterial thinking
} spirits. 
That is just one example of the ways in which Locke's discussion in this chapter seems to have been guided by Cudworth's discussion. ${ }^{14}$ Others will emerge below.

Beyond the broad argument above, there are other arguments in IV.x.10 against incogitative matter producing a thinking intelligent being. These are not, I suggest, aimed at the view that there is a material thinking God. Rather, they are aimed at someone who grants Locke the central goal of his cosmological argument, but suggests that the first cause is an incogitative, rather than a cogitative being. Thus, when Locke argues in this section that incogitative matter could never produce thought, he is arguing that it could never be the efficient cause of thought, not that it could never be the underlying stuff from which thought emerged. ${ }^{15}$

Michael Ayers reads that claim differently, taking Locke to have previously established that the eternal being is cogitative, then argued in IV.x.10 that it cannot also be material. ${ }^{16}$ Thus Ayers's discussion is phrased in terms of what can flow from the essence of matter. That, I am

${ }^{14}$ Fairly soon after the quoted passage, Cudworth gives an extended discussion of 'the Achilles of the Atheists; their Invincible Argument, against a Divine Creation and Omnipotence; because Nothing could come from Nothing' (TIS 738-67). That discussion of principles about causation, and their consequences for how we think about God, is particularly relevant to Locke's chapter. Locke himself noted this section and its attention to creation ex nihilo as one of four themes from the True Intellectual System (John Locke, An Early Draft of Locke's Essay, Together with Excerpts from his Journals, edited by R.I. Aaron and Jocelyn Gibb [Oxford: Clarendon, 1936], 118).

${ }^{15}$ Was Locke attacking some philosopher in particular here? Hobbes is one possibility. Locke owned some works of Hobbes's, including most relevantly the 1651 edition of Leviathan (The Library of John Locke, \#1465, p. 155). At least until the 1651 Leviathan, Hobbes believed in a first cause, the nature of which we do not know. He made no claim about that first cause being a thinking thing. Indeed, he said that knowledge and understanding could not be attributed literally to God (Leviathan 31.27). Thus one might think that Hobbes's first cause is an incogitative being, which is somehow the ultimate cause of the thinking beings in the world. What exactly Hobbes believed about the first cause is a matter of continuing discussion. See Arash Abizadeh, 'Hobbes's Agnostic Theology before Leviathan', Canadian Journal of Philosophy, 47 (2017), 714-37; Thomas Holden, 'Hobbes's First Cause', Journal of the History of Philosophy, 53 (2015), 647-67; and R.W. McIntyre, 'Concerning "men's affections to Godward": Hobbes on the First and Eternal Cause of All Things', Journal of the History of Philosophy, (2016) 54, 547-71.

${ }^{16}$ Ayers, Locke, 2: 174ff. 
arguing, is not what is going on in IV.x.10, in contrast with later sections. Ayers, however, moves in his discussion from a passage in IV.x.10 to a passage in IV.x.16, as if they were addressing the same issue. ${ }^{17} \mathrm{I}$ hope to show that, though there clearly are connections between the two discussions, the aims of the arguments are importantly different.

Why read IV.x.10 as I suggest? ${ }^{18}$ First, it makes this section fit sensibly after the distinction between cogitative and incogitative beings. Secondly, it helps avoid a puzzle that otherwise arises - if one takes IV.x.10 just to be arguing against the possibility of a material thinking God, then one has to explain why Locke argues against the very same view in sections 13-17. Thirdly, one reason why Locke is concerned with the efficient causation of a thinking being is that this is central to his initial argument in the chapter-Locke's cosmological argument focuses on the causation of the existence of the thinking being giving the argument. ${ }^{19}$

I believe those considerations are decisive as to the main aim of the section. There is, however, a passage towards the end of the section that seems not to fit my reading. This is a passage that Locke added in the second edition (and retained in later editions). ${ }^{20}$ In it, Locke mentions what would happen 'if Matter were the eternal first cogitative Being'. That is, in the added passage, Locke argues against a cogitative material first being, not an incogitative one. I cannot deny the existence of this passage, but it should not distract us from the above point about the main purpose of IV.x.10. Locke has been arguing that bare incogitative matter could not

\footnotetext{
${ }^{17}$ Ayers, Locke, 2: 177-8.

18 Patrick Connolly, 'Thinking Matter in Locke's Proof of God's Existence' ['Thinking Matter'], Oxford Studies in Early Modern Philosophy 9 (2019), 105-30, makes a similar point about the role of section 10 in the chapter. I also, as will become clear, agree with his thought that Locke is not arguing from inconceivability to impossibility. We do however reach rather different conclusions about what Essay IV.x shows about superaddition ('Thinking Matter', 129).

${ }^{19}$ Moreover, Locke in the Essay tends to use 'produce' to describe a relationship of efficient causation, which suggests he is doing the same here.

${ }^{20} E$ p.624, lines 11-25.
} 
produce thinking beings. That leads him to say that matter could only produce thinking beings if it could already think. Having said that, Locke could simply refer forward to later arguments against that view. He chooses, however, to consider briefly what fundamentally thinking matter might be like, and to give a quick argument against that notion. ${ }^{21}$ But at the end of the section he returns to its main point, that the first cause must be a cogitative being. ${ }^{22}$

One might wonder why Locke added this passage to the second edition of the Essay, especially if, as I suggest, it takes us away from the main point of the section. The answer can be found in correspondence between Locke and Molyneux from 1693. ${ }^{23}$ Molyneux pointed out that some readers saw a contradiction between IV.x.10 and IV.iii.6. ${ }^{24}$ In his response, Locke discussed adding a passage to IV.x.10 to clear up that confusion—namely, the passage I am discussing here. ${ }^{25}$ It is not entirely clear why Locke thought that adding this passage would help. But it did allow him to state his overall view that the first cause could not be matter (cogitative or incogitative), not just his narrower view that it could not be incogitative matter. Thus, Locke perhaps hoped to emphasize the contrast between the claim that we might be material (in some way) and the claim that God could not be (in any way).

${ }^{21}$ This prefigures later arguments that criticize several versions of the view that the first cause is both thinking and material. The view targeted in this passage resembles the one criticized in IV.x.14. But here it is criticized for a different reason - that if there were many cogitative material beings, they could not produce the 'order, harmony, and beauty' of nature. See the discussion of IV.x.14 in section 4.2 below, and also the discussion of the section 10 passage by Stuart, Locke's Metaphysics, 253-6.

${ }^{22}$ In the final sentence Locke states his broader view that the 'first eternal Being cannot be Matter' (cogitative or incogitative) but the argument he gives is against it being incogitative. I discuss that argument in section 4.3 below.

${ }^{23}$ This discussion is noted by Connolly, 'Thinking Matter', 124.

${ }^{24} \mathrm{He}$ also noted that there is not a contradiction, because 'in the first [E IV.iii.6] tis said, that we cannot tell [...] but an Almighty God may make matter think. In the other [E IV.x.10] tis asserted that Unthinking Matter cannot be this Almighty God' (Locke, Corr. 4: 600).

${ }^{25}$ Corr. 4: 624. In replying, Molyneux suggested that Locke add a marginal note in the Essay saying that this new passage was supposed to clear up the 'seeming Repugnancy' (Corr. 4: 648), but Locke did not do so. 
3.2 The Main Argument of Essay IV.x.10 is not an

Inconceivability Argument

If we look more closely at IV.x.10, we find Locke arguing first that matter itself 'cannot produce in it self so much as Motion', then that even if matter has motion added to it, it could never produce thought. That Locke denies these two things is clear. But why?

There is textual evidence for reading Locke as giving inconceivability arguments here, arguments that rely on a move from ' $\mathrm{X}$ is inconceivable' to ' $\mathrm{X}$ is impossible'. He says, for instance, that:

For Example; let us suppose the Matter of the next Pebble, we meet with eternal, closely united, and the parts firmly at rest together, if there were no other Being in the World, Must it not eternally remain so, a dead inactive Lump? Is it possible to conceive it can add Motion to itself, being purely Matter, or produce any thing? Matter then, by its own Strength, cannot produce in itself so much as Motion: The Motion it has must also be from Eternity, or else be produced, and added to Matter by some other Being more powerful than Matter; Matter, as is evident, having not Power to produce Motion in itself (IV.x.10).

This appears to turn on a claim about what it is 'possible to conceive'. Later, and similarly, Locke writes 'I appeal to every one's own Thoughts, whether he cannot as easily conceive Matter produced by nothing, as Thought to be produced by pure Matter, when before there was no such thing as Thought, or an intelligent Being existing?' (IV.x.10). That is, it looks as if Locke argues from the premise that it is inconceivable that bare matter give rise to motion, or 
moving matter to thought, to the conclusion that it is impossible that bare matter give rise to motion, or moving matter to thought.

It would however be surprising to find Locke giving such arguments, for he cautions against using inconceivability arguments, in particular against using them to reach conclusions about the nature of the human mind. Earlier in book IV, he rejects the arguments of those:

Who, either on the one side, indulging too much to their Thoughts immersed altogether in Matter, can allow no existence to what is not material: Or, who on the other side, finding not Cogitation within the natural Powers of Matter, examined over and over again, by the utmost Intention of Mind, have the confidence to conclude, that Omnipotency it self, cannot give Perception and Thought to a Substance, which has the Modification of Solidity (E IV.iii.6).

Both of these errors are described as resulting from:

An unfair way which some Men take with themselves; who, because of the inconceivableness of something they find in one, throw themselves violently into the contrary Hypothesis, though altogether as unintelligible to an unbiassed Understanding (E IV.iii.6).

That is, Locke cautions against establishing materialism or dualism about the human mind on the basis of an inconceivability argument. ${ }^{26}$ At the very least he thinks one should not base either view on a simple inconceivability argument, one that makes the move from inconceivability to impossibility without offering any further support for the impossibility claim. ${ }^{27}$

${ }^{26}$ On these criticisms, see Stewart Duncan, 'Toland, Leibniz, and Active Matter', Oxford Studies in Early Modern Philosophy 6 (2012), 249-78, at 271-8.

${ }^{27}$ Locke even emphasizes the weakness of a reliance on inconceivability arguments later in Essay IV.x itself: 'it is not reasonable to deny the power of an infinite being, because we cannot comprehend its operations. We do not deny other effects upon this ground, because we cannot possibly conceive the manner of their production' ( $E$ IV.x.19). 
If Locke were giving simple inconceivability arguments in IV.x.10, he would be making the same sort of arguments he criticizes elsewhere (and not far away, at that). They would not be exactly the same arguments, but they would be using the same sort of inconceivability claims in the same sort of way, and would indeed be about similar topics. It is thus highly implausible that Locke in IV.x.10 is just giving an inconceivability argument against incogitative matter producing thought.

\subsection{The Main Argument of IV.x.10 is an Argument About the}

Causation of Perfections

Is there more we can say about the argument of IV.x.10? Does Locke have some other reason for his impossibility claims in IV.x.10, one that might supplant or support the inconceivability claims?

For a clue to this, we might look at Cudworth. In his discussion of 'the Achilles of the Atheists', Cudworth offers an argument similar to that of Essay IV.x.10:

if Matter as such, have no Animal Sense and Conscious Understanding, Essentially belonging to it, (which no Atheists as yet have had the Impudence to assert) then can no Motion or Modification of Matter, no Contexture of Atoms, Possibly beget Sense and Understanding, Soul and Mind; because this would be to bring Something out of Nothing, in the Impossible Sense, or to suppose Something to be Made by It self without a Cause (TIS 758).

Cudworth argues that matter and motion cannot give rise to sense and understanding. He supports this claim with a discussion of the principle that you cannot get something from nothing. In particular, Cudworth thinks the atomic materialism he is discussing violates a 
principle about the causation of perfections. Sense and understanding are more perfect than motion and the modifications of matter, so the latter cannot cause the existence of the former.

Cudworth's argument relies on a hierarchy of perfection, and a principle about what can cause what, given their levels of perfection. There is good evidence that Locke has something similar in mind in IV.x.10. Look at how Locke ends the section:

Since therefore whatsoever is the first eternal Being must necessarily be cogitative; And whatsoever is first of all Things, must necessarily contain in it, and actually have, at least, all the Perfections that can ever after exist; nor can it ever give to another any perfection that it hath not, either actually in it self, or at least in a higher degree; It necessarily follows, that the first eternal Being cannot be Matter ( $E$ IV.x.10). ${ }^{28}$

Here Locke is giving something like Cudworth's argument. Of course, one might take Locke to be giving two arguments in the section, one based on inconceivability and the other on degrees of perfection. I suggest it makes more sense to think of the section as unified. The reasoning about perfection is, on this reading, the underlying support for the claims of inconceivability. (Thus we cannot conceive of the less perfect causing the more perfect, because such causation is impossible.) If we read the section this way, we also avoid concluding that Locke here gave the sort of simple inconceivability argument he criticized elsewhere.

The driving force of the argument of IV.x.10 is Locke's view that a being with less perfect features cannot cause more perfect features to exist in the world. The argument is not independent of Locke's claims about the inconceivability of an incogitative being causing the

\footnotetext{
${ }^{28}$ John Norris, Christian Blessedness, or, Discourses upon the Beatitudes of our Lord and Saviour Jesus Christ [...] to which are added, Reflections upon a late Essay concerning Human Understanding (London, 1690), 30, notices this passage, commenting: 'God then, even according to him, is all Beings; or, has the whole Plenitude of Being. And I wonder that this Principle had not led this Sagacious Person further'. Further, that is, towards Norris's own view.
} 
existence of thinking ones. Rather, the views about perfection and causation support the inconceivability claims, ensuring that Locke is not giving the simple sort of inconceivability argument that he himself criticizes.

\subsection{Locke's Hierarchy of Perfections}

I argued above that a hierarchy of perfection plays an important role in Locke's thinking in Essay IV.x. There is evidence throughout the Essay of Locke's belief in such a hierarchy. Consider this passage from a little later in Book IV:

Observing, I say, such gradual and gentle descents downwards in those parts of the Creation, that are beneath Man, the rule of Analogy may make it probable, that it is so also in Things above us, and our Observation; and that there are several ranks of intelligent Beings, excelling us in several degrees of Perfection, ascending upwards towards the infinite Perfection of the Creator, by gentle steps and differences, that are every one at no great distance from the next to it ( $E$ IV.xvi.12).

Locke aims here to emphasize the gradual nature of the differences between beings, or kinds of beings, but these are gradual differences within a hierarchy, the highest point of which is 'the infinite perfection of the Creator'.

More generally, the Essay illustrates Locke's commitment to two related hierarchies of perfection: a hierarchy of beings, and a more fundamental hierarchy of features of those beings. The hierarchy of beings stretches from God, to spirits which are superior to us, to us, to other animals, and on down. Those are the ways in which kinds of things generally line up, but we should think of Locke's hierarchy of beings as fundamentally a hierarchy of individuals, not of 
kinds. ${ }^{29}$ Locke thinks that human individuals are usually more perfect than non-human animals, but he is not committed to that always being the case. ${ }^{30}$ That hierarchy of individuals itself depends, however, upon a hierarchy of features.

I agree with Ayers that the hierarchy of features is what is basic for Locke. It is less clear to me that this is, as Ayers claims, a modification of Cudworth's view—-that Locke has done something new by having a scale of 'valuable and remarkable attributes' rather than Cudworth's 'scale of different types of substance'. ${ }^{31}$ Certainly sometimes Cudworth talks as if he believes in a hierarchy of features: notice for example the important roles of sense and understanding in the passage quoted above (TIS 758). One can—in fact one ought to — grant Ayers that Cudworth believes some features belong to substances of one kind, some to substances of another, and there are sharp divisions between the kinds. None of that, however, stops the hierarchy of features being prior to, and what explains, the hierarchy of beings.

God is atop Locke's hierarchy of beings. He has 'perfect Wisdom' (E I.iv.21). More generally, the 'Degrees or Extent, wherein we ascribe Existence, Power, Wisdom, and all other Perfection, (which we can have any Ideas of) to that Sovereign Being which we call God' are 'all boundless and infinite' ( $E$ II.xxiii.34). The perfect being's features are perfections or excellencies, each of which he has to that boundless extent. Moreover God 'is infinitely more remote, in the real excellency of his nature, from the highest and perfectest of all created beings, than the greatest man, nay purest seraph, is from the most contemptible part of matter' $(E$

${ }^{29}$ Various puzzling questions threaten to arise. For example: given that individuals of a species can have different levels of perfection, does Locke's view about the causation of perfections commit him to the view that children cannot be more perfect than their parents?

${ }^{30}$ See for example $E$ III.vi.26.

${ }^{31}$ Ayers, Locke, 2: 171-2. 
III.vi.11). As we see there, Locke talks about spirits which are inferior to God but superior to us: 'Cherubims, and Seraphims, and infinite sorts of Spirits above us' (E IV.iii.17). ${ }^{32}$

Humans rank below angels in the hierarchy of perfection, but above many other creatures. The reason for our place in the hierarchy of beings is our mental capacities' place in the hierarchy of features. Humans have 'the perfection of rational thinking' ( $E$ II.i.16). Memory is another perfection, though it may be possessed in a greater degree by higher beings: 'For who can doubt, but God may communicate to those glorious Spirits, his immediate Attendants, any of his Perfections, in what proportion he pleases, as far as created finite Beings are capable' (Essay II.x.9). God's perfection here is omniscience, and the memory of created beings is their lesser version of this. Meanwhile, the power of abstraction is another excellency that non-human animals lack (E II.xi.5). More generally, 'the most excellent Part of his [God's] Workmanship' is 'our Understandings' ( $E$ IV.xviii.5). ${ }^{33}$

It is clear that Locke is committed to hierarchies of perfection. ${ }^{34}$ That itself does not commit him to the principle about causation and perfection that is needed for the argument of Essay IV.x.10. Locke was familiar with such principles from the work of Cudworth and Descartes. Cudworth, as we saw above, thought that for a less perfect thing to cause a more perfect one 'would be to bring Something out of Nothing, in the Impossible Sense, or to suppose Something to be Made by It self without a Cause' (TIS 758). If this happened, then nothing

\footnotetext{
${ }^{32}$ For further examples, see $E$ II.x.9, II.xxiii.36, III.vi.12, III.i.23, IV.iii.17, and IV.xvii.14.

${ }^{33}$ See also E II.i.15, II.ix.4, II.xxiii.5, IV.iv.15, IV.xiv.2, and Works 4: 460-3.

${ }^{34}$ We also see a hierarchy of perfection in Descartes's work, but Descartes's hierarchy is a rather rough one, which tells us just that an infinite substance is more perfect than a finite one, which is more perfect than modes or accidents (AT 7: 165,185). Michael Della Rocca, 'Causation without Intelligibility and Causation without God in Descartes', in Janet Broughton and John Carriero (ed.), A Companion to Descartes (Malden, MA: Blackwell, 2008), 235-50, at 239, finds suggestions that Descartes thought there was a more fine-grained hierarchy, with finite minds being more perfect than finite bodies, and more complex bodies more perfect than less complex ones, but the evidence for this is far from overwhelming.
} 
would explain the existence of the perfection of the new thing - the cause could not explain it, and nothing else could either. ${ }^{35}$ Moreover, a principle about causation and perfection had already been at work earlier in the chapter, when Locke argued in sections 4 and 5 that the first being must be the most powerful, and also knowing and intelligent. Locke's stated principle in section 4 is that 'whatever had its Being and Beginning from another, must also have all that which is in, and belongs to its Being from another too. All the Powers it has, must be owing to, and received from the same Source'. Received from is key here-Locke wants to rule, out, for example, the case in which an unthinking first cause gives rise to a thinking being. How exactly he proposes to do that is not exactly clear in section 4 , but the reasoning about perfection that becomes more explicit later would make sense of that too. ${ }^{36}$ Though the principle about the causation of perfection is not visible throughout the Essay, it is something that Locke is clearly committed to in Essay IV.x. ${ }^{37}$

${ }^{35}$ Descartes likewise believed that a less perfect thing could not cause a more perfect one. If such causation were to take place, the additional perfection in the effect would have been (objectionably) caused by nothing. In Descartes' case, there was a further complication: he did not just claim that it was impossible for less perfect things to cause the existence of more perfect things, but also that it was impossible for less perfect things to cause the existence of thoughts of more perfect things. This further complication has its own puzzles, but happily they need not detain us here, except to note that Locke clearly rejects this view. Locke thinks we perfectly well can, as finite beings with experience of the finite, construct an idea of a perfect being ( $E$ II.xxiii.34-6).

${ }^{36}$ For Locke, as for other advocates of such principles, there seems to be an underlying commitment to a certain causal model of the transmission of perfections from cause to effect. The perfection that is received by the effect may be a weaker version of that in the cause, but can never be greater, for where could that extra perfection have come from?

${ }^{37}$ Connolly ('Thinking Matter', 107) names the relevant principle 'CONTAINMENT', which 'means that a cause must contain the powers had by its effect' (107). We seem to be in broad agreement about the claim that is involved here, but unlike Connolly I would also include Locke among those 'early modern authors [who] approach this through the claim that causes must be at least as perfect as their effects'. Connolly contrasts talk of perfection with talk of powers, but for Locke some perfections are powers. (See note 60 below for a possible consequence of this disagreement about how to frame the causal principle.) 
Locke's commitment to hierarchies of perfection is apparent throughout the Essay. In Essay IV.x, he shows he is also committed to a principle about the causation of perfections. These two commitments are employed, in Essay IV.x.10, in an argument that the first cause- the eternal being Locke had argued for earlier — cannot be an incogitative being. This argument rules out the possibility that the eternal being is mere incogitative matter. But another possibility remains: that the first cause is some sort of cogitative material being, not mere matter but a material God.

\section{MATERIAL GODS}

\subsection{The Aims of IV.x.13-17}

By the end of Essay IV.x.10, Locke thinks he has ruled out the view that the first cause is incogitative. A question remains though — what if God is both cogitative and material? As Locke puts the issue: 'perhaps it will be said, that though it be as clear as demonstration can make it, that there must be an eternal Being, and that being must also be knowing; yet it does not follow, but that thinking Being may also be material' ( $E$ IV.x.13). Sections 13 through 17 respond by arguing against the view that there is a material cogitative God. ${ }^{38}$

Locke's first objection to the material God view is in section 13, where he suggests that people who think this will tend to slide towards thinking there is just matter and no God, even though this is not really their considered view. He also argues, quickly, that these people ought to acknowledge an eternal immaterial thinking being. If (i) they think there can be matter without thought, then (ii) they think there is no necessary connection between matter and thought, and so

${ }^{38}$ Descartes considered similar issues briefly in Principles of Philosophy 1.23, which says that 'God is not corporeal and does not perceive by means of the senses as we do, nor is he the originator of sin' (AT 7A: 13, CSM 1: 200). This was not a new thing to do. For instance, Aquinas had addressed the view that God is a body early in his Summa Theologiae (I, Q3, A1). 
(iii) the previous demonstration of an eternal thinking being does not show there's a material God, just a God, and (iv) supposing God to be material is to no purpose. Locke does not take those thoughts to settle the issue though. Instead he distinguishes and considers versions of the material God view. The question used to distinguish the options seems to be, how could a material first being be a thinking being? The options are: that matter is essentially and irreducibly thinking (either all of it, or just one atom), or that the material God is a material system, the thought of which emerges from the structure and motion of its parts. Ultimately, Locke thinks that neither of these options is acceptable. Thus, Locke's answer to the guiding question of these sections, could the first cause be a cogitative material being?, is another firm 'no'.

Locke might seem just to be working through possible things one might think in this realm, but there were, in fact, philosophers of the time who believed that God was material. Hobbes, for instance, held in the 1660 s that God was a 'pure, simple, invisible spirit corporeal' ${ }^{39}$ One might also wonder whether Locke had Spinoza in mind here. Several of Spinoza's early English readers understood him to think there was exactly one substance (which he called God) that was material in the same way that familiar bodies are (only larger). Spinoza, thus understood, was a materialist about all creatures, nature as a whole, and God as well. Henry More had offered such a materialist interpretation in 1679, saying that 'Spinoza means by God nothing more than infinite matter necessarily acting by itself' ${ }^{40}$ Though we do not know how

${ }^{39}$ Hobbes, EW 4: 313. For recent discussions of this view of Hobbes's, see Geoffrey Gorham, 'The Theological Foundations of Hobbesian Physics: A Defense of Corporeal God', British Journal for the History of Philosophy 21 (2013): 240-61; his 'Mixing Bodily Fluids: Hobbes's Stoic God', Sophia 53 (2014): 33-49; and Patricia Springborg, 'Hobbes's Challenge to Descartes, Bramhall and Boyle: A Corporeal God', British Journal for the History of Philosophy 20 (2012): 903-34.

${ }^{40}$ Henry More, Henry More's Refutation of Spinoza, edited and translated by Alexander Jacob (Hildesheim: G. Olms, 1991), 78. This translates More's Demonstrationis Duarum 
Locke understood Spinoza, More's reading gives us a way to see that Locke's arguments against a material cogitative God might have been aimed in part at Spinoza.

Nevertheless, although Locke may have thought that Hobbes and Spinoza believed in material Gods, his argument against material God views does not proceed by interpreting their texts and objecting to the views he finds there. That's not often a way Locke proceeds in the Essay, even when he does seem to have targets in mind. Instead, Locke proposes his own categorization of ways in which material God views might work, and then opposes each sort of view. All this being so, it portrays Locke's target too narrowly to say, as Lisa Downing does, that 'Locke's central concern in E IV.x is to eliminate Hobbes's God' ${ }^{41}$ Hobbes is a target, but Spinoza is perhaps one as well, and other versions of the material God view are also considered.

\subsection{Against Material God Views on Which Some Matter is \\ Essentially and Irreducibly Thinking}

In section 14, Locke considers the view that every particle of matter thinks, and has always done so. He notes that his opponents are unlikely to accept this, because it involves many eternal thinking beings, not one single material God: 'there would be as many eternal thinking Beings, as there are Particles of Matter, and so an infinity of Gods'. If the material God theorist is aiming for a view on which there is a material God, one single first thinking being, Locke seems right that holding this position is not a good option for them, as there is nothing to distinguish any one

Propositionum, on Spinoza's Ethics, which was published in Henry More, Opera Omnia (London, 1679), 615-35. There is however no record of Locke owning More's Opera Omnia, though he did own several of More's other works (The Library of John Locke, \#2043-2047a, p.192). He also owned several of Spinoza's works: the book on Descartes' Principles, the Tractatus Theologico-Politicus, and the Opera Posthuma (The Library of John Locke, \#2518, p.223, \#2742-4, p.238).

${ }^{41}$ Lisa Downing, 'Locke's Ontology', in Lex Newman (ed.), The Cambridge Companion to Locke's Essay (Cambridge: Cambridge University Press, 2007), 352-80, at 378. 
of the particles as the material God. ${ }^{42}$ Despite that, Locke does suggest that this is the best way for his opponents to explain how the material God can think. ${ }^{43}$ On other versions of their view, not all matter can think. Thus the question arises of how some of it can, if it cannot all do so.

One way to avoid the apparent problem about an infinity of thinking beings would be to hold that only one particle of matter, one 'atom' as Locke says, could think. Locke distinguishes and rejects two versions of this view in IV.x.15.

The first version holds that the single thinking atom was the first being, and that it produced the rest of matter. Locke notes that there is creation ex nihilo on this account, and argues that the materialist should reject this option because they reject such creation. Indeed, it's striking how much Locke takes the materialists he's engaging with to be worried about creation ex nihilo. However, creation ex nihilo is not obviously something that either Hobbes or Spinoza was much concerned about.

Hobbes, for example, mentions creation several times in Leviathan without discussing its nature. There is some discussion of creation in Hobbes's work on Thomas White's De Mundo, but there he raises problems about White's account, not creation itself. ${ }^{44}$ Spinoza, meanwhile, does explicitly criticize talk of creation ex nihilo, but he does this only to argue that the 'ex' is misleading, its use suggesting that there is a thing called 'nothing' from which new things have been created. He argues that one should instead understand creation as the 'activity in which no

${ }^{42}$ The question of whether God is unique arises in Locke's correspondence with van Limborch (Corr. letters 2340, 2395, 2413).

43 'And yet if they will not allow Matter as Matter, that is, every particle of Matter to be as well cogitative, as extended, they will have as hard a task to make out to their own Reasons, a cogitative Bring out of incogitative Particles, as an extended Being, out of unextended Parts, if I may so speak' ( $E$ IV.x.14).

${ }^{44}$ Thomas Hobbes, Critique du De Mundo de Thomas White, edited by Jean Jacquot and Harold Whitmore Jones (Paris: Vrin, 1973), 364-6; Thomas White's De Mundo Examined, translated by Harold Whitmore Jones (London: Bradford University Press. 1976), 385-8. See Robert Pasnau, Metaphysical Themes 1274-1671 (Oxford: Oxford University Press, 2011), 22-7 and 31-3. 
causes concur except the efficient' ${ }^{45}$ Now, Spinoza did reject creation, at least as others understood the notion. Maybe Hobbes did so too. But the discussion and rejection of creation is not a key argumentative move for them, as Locke presents it as being for materialists.

Locke's thought that materialists are concerned with creation ex nihilo may be explained by the way Cudworth had framed the debate for Locke. Cudworth clearly portrays his opponents as concerned with this issue. For example, one argument Cudworth discusses is: 'By God is alwayes Understood, a Creator of some Real Entity or other out of Nothing; but it is an Undoubted Principle of Reason and Philosophy, an Undenyable Common Notion, That Nothing can be made out of Nothing, and therefore there can be no such Creative Power as this' (TIS 738). That is, creation ex nihilo is a violation of the principle that you cannot get something from nothing, and so one should not believe in a divine creator. Cudworth rejects that, obviously. But he repeatedly emphasizes, in the section on the Achilles of the atheists, the question of the possibility of creation. ${ }^{46}$

The second version of the single atom view holds that all matter is eternal, but that only one atom of it can think. This avoids the alleged problem about creation, but there is now a question as to why this one atom can think when the other parts of matter cannot. Locke says this is absurd, and that there is no reason to say it - even if this might be possible, why think it is true?

In addition, Locke seems to argue that all matter has the same nature, so there cannot be one atom with a different nature: 'Every particle of Matter, as Matter, is capable of all the same

\footnotetext{
45 The discussion is in the chapter (X) on creation in the 'Appendix concerning Metaphysical Thoughts' to Spinoza's book on Descartes' Principles (C 1: 333-9).

${ }^{46}$ Creation ex nihilo continued to be an aspect of the debate in the Clarke-Collins correspondence. Samuel Clarke and Anthony Collins, The Correspondence of Samuel Clarke and Anthony Collins, 1707-08, edited by William L. Uzgalis (Peterborough, ON: Broadview, 2011), 245-6.
} 
Figures and Motions as any other; and I challenge any one in his Thoughts, to add any Thing else to one above the other' ( $E$ IV.x.15). It is unclear, however, why one should not say that the special atom, as matter, 'is capable of all the same Figures and Motions as any other' atom, but because it is also thinking matter, is also capable of thought. Consider an analogy: a dog, as an animal, is a living thing, but as a dog is capable of barking. Locke may well be right that it is hard to find reasons and evidence for the one thinking atom view, but his explicit arguments against it appear problematic. ${ }^{47}$

\subsection{Against the View That the Material God is a Material System}

The above versions of the material God view take some or all matter to be fundamentally and irreducibly thinking. That was an unusual choice for a seventeenth-century materialist. ${ }^{48}$ The more obvious, mechanistic approach was to say that that a properly organized material system gave rise to thought. In Essay IV.x.16 Locke discusses a version of that view, on which the organization of a material system is used to account for the thought of the first being, the material God. Locke disapproves:

to suppose the eternal thinking Being, to be nothing else but a composition of Particles of Matter, each whereof is incogitative, is to ascribe all the Wisdom and Knowledge of that

\footnotetext{
${ }^{47}$ A defender of Locke might argue as follows: the additional thought of the one atom cannot be an accidental feature of it, for then there would be no explanation of the thought's presence; so it must be an essential feature; but then it must belong to all matter. (Superaddition would be different, and not ruled out by this argument, for in the superaddition case, thought's presence in a body would be accidental but explained.) This argument relies however on a non-Lockean view of essences. One can apparently say, on Locke's view, that both the thinking atom and the rest of matter are matter, because they share the nominal essence of matter, even though they also differ in an important way.

${ }^{48}$ One would have to put this point somewhat differently, if one thought that Spinoza was a materialist. Meanwhile, although she did not think God was material, Margaret Cavendish had proposed a view of matter as fundamentally thinking. Cudworth commented briefly on her view (TIS 137-8).
} 
eternal Being only to the juxta-position of parts; than which, nothing can be more absurd.

For unthinking Particles of Matter, however put together, can have nothing thereby added

to them, but a new relation of Position, which 'tis impossible should give thought and

knowledge to them (E IV.x.16).

According to Locke, the wisdom, knowledge, and thought of the eternal being cannot be explained by the arrangement of the parts of a material being. Indeed, Locke thinks that no amount of wisdom, knowledge, and thought, no matter how small, could be explained this wayit is not the high degree of God's possession of these features that is at issue. Why does he think this?

I suggest that thoughts about degrees of perfection are again at work in the background here, supporting the impossibility claim. Reading the argument in this way, Locke's claim of absurdity would be explained. This argument would be like that in Essay IV.x.10, though there would still be a difference between them. The argument in section 10 is about the efficient causation of thought. The argument in section 16 appears to be about a synchronic grounding relation, which one might want to distinguish from efficient causation. Locke seems inclined to assimilate the two cases though. Indeed, his final comment about a new relation of position, a rearrangement of the particles, not giving thought to them, suggests an inclination to think about this as an efficient causation case. ${ }^{49}$

${ }^{49}$ Connolly claims that Locke thinks 'it would be possible for a material object to think prior to any act of superaddition on God's part' ('Thinking Matter', 2). It is true that Locke grants (at least for the sake of argument) the possibility that God might be a thinking material being, and his argument against that view is not just that it is impossible for matter to think. But it is not clear to me that we can find passages where Locke himself suggests it is possible that matter think, absent superaddition. Moreover, Locke's argument in IV.x.16 does, as I understand it, try to rule out thought being grounded in the structure and motion of the parts of an organized material system. 
Section 17 offers a further argument against the view of God as an organized material system. Either, Locke says, the parts of that system are at rest or they are in motion. If they are at rest, then this system cannot think any more than an atom can: that is, merely having a number of atoms, or even a structure of them, cannot introduce thought. The second option is that (some of) the parts of the system are in motion. Against that, Locke offers an argument that turns on the regulation and guiding of motion. The core idea is that thought cannot be produced by unguided motion - how could the parts possibly move in the right way if they do not know which way to move?

Here Locke does not quite argue that it would be impossible for such a system to think. Rather he argues that, even if it were able to think, it would not be able to think well-there would be no rationality or wisdom in such a system. Locke's reason concerns the regulation of motion. Even according to the materialist, only the right motions will produce thoughts. But, Locke argues, the right motions will only be produced if the matter is suitably guided. That guiding cannot happen in this particular materialist picture though, for there is nothing to guide the particles of the system.

Locke is once again echoing Cudworth, among others. The idea that matter needs some external, immaterial guide to produce the features of the world we live in is a prominent one in the True Intellectual System. Indeed it is Cudworth's central reason for the existence of plastic natures, the immaterial beings he thinks guide the workings of the material parts of the created world (TIS 146-82). Moreover, there are again connections to Descartes: consider his comment in the First Meditation on what we would be like as epistemic agents if there were no God (AT 7: 21). According to Descartes, if I were merely the result of a chance combination of material objects, I would be extremely imperfect epistemically, no good at all at forming true beliefs 
about the world. I would, that is — and here we see the connection to Locke — not be able to think well, if I were such an unguided material system.

\section{SUPERADDITION}

The arguments of Essay IV.x are just part of Locke's discussion of materialism. We might hope that considering those arguments can help us better understand another part of that discussion, what Locke says about the superaddition of thought to matter. In this section I argue that they do help us in this way. First, I show how Locke's discussion in IV.x is consistent with his discussion elsewhere of superaddition, given my reading of IV.x. Secondly, I argue that my reading of IV.x gives us an argument for one particular understanding of superaddition.

\subsection{Consistency}

The arguments of Essay IV.x oppose some sorts of materialism. Earlier on however, Locke had argued for the possibility of another sort of materialism. For he had argued that God could 'if he pleased, give to certain Systems of created senseless matter, put together as he sees fit, some degrees of sense, perception, and thought' ( $E$ IV.iii.6). That is, Locke says it is possible that humans' power of thought is the result of God superadding thought to the matter in us, rather than giving us an immaterial thinking mind. One might wonder-and readers of Locke have long wondered - whether there is a tension between these two sets of arguments. ${ }^{50}$

50 Downing, 'Locke's Ontology', for example, is framed in terms of this 'tension' (353), and the 'alleged inconsistency' is similarly noted early in Martha Brandt Bolton, 'Locke on Thinking Matter', in Matthew Stuart (ed.), A Companion to Locke (Chichester: Blackwell, 2015), 334-53, at 335. As I noted in section 3.1 above, Locke discussed this apparent tension in correspondence with Molyneux in 1693. 
Think back first to IV.x.10, and the argument about the causation of perfections. Notice that the principle about perfection and causation that is so important in IV.x.10 generates no objection to God superadding thought to matter. In the superaddition case, God, the most perfect being, would be the efficient cause of the presence of this lesser perfection in us, which is entirely consistent with what is said in IV.x.10. The argument of IV.x.17 against God being a material system is also relevant. Here again, there is nothing that rules out superaddition. Locke argues that an undesigned material system could not think wisely. A material system to which God superadded thought would not be subject to this criticism. However exactly we take superaddition to work, it will involve God deliberately creating the thinking material being, and thus the presence of a guiding mind.

Here I take Locke to be seeing a possibility that Cudworth did not see, in contrast to Ayers who has Locke modifying Cudworth's view to create this possibility. ${ }^{51}$ For superaddition is also consistent with Cudworth's principles in this area. Consider the relevant sense of the principle about not getting something out of nothing: 'Nothing can be Efficiently Caused or Produced, by that which hath not in it at least Equal, (if not Greater) Perfection, as also Sufficient Power to Produce the same' (TIS 339). This is consistent with the superaddition of thought to matter, if in that case we understand God as the efficient cause of thought in thinking matter. Thus, even Cudworth's ordering of perfections, and his causal principle, do not rule out superaddition. Cudworth may not himself have seen that possibility, but Locke did.

Focusing again on Locke, I emphasize that my reading of Essay IV.x yields a view that is consistent with the claims of Essay IV.iii.6. This is, I think, an issue on which it is particularly desirable to be able to read Locke as being consistent. For in IV.iii.6 Locke refers forward to his

${ }^{51}$ Ayers, Locke 2: 169-83. 
own argument in IV.x that it is impossible that the eternal thinking being should be material. That is, Locke explicitly thought and said that he could make his claim about superaddition, despite the argument of IV.x. Of course it is possible that he missed some contradiction, but he had the consistency of the two claims in mind.

\subsection{Beyond Consistency}

Those points about consistency are worth noting, but limited. I want to argue, however, that there are stronger connections between the discussion of Essay IV.x and the issue of superaddition, and that Locke's views about perfection and causation suggest a particular reading of what superaddition is.

The secondary literature on Locke contains several readings of his views on superaddition. One central question on which they differ is this: 'did Locke claim that some bodies have powers which do not flow from their nature, or real essence'? ${ }^{52}$ That is, does Locke think that a feature superadded to a body flows from its nature (in a way in which he seems to think other features do) or not? ${ }^{53}$

If one thinks that superadded features do not flow from bodies' natures, the question arises of where these features - most relevantly, the power of thought in a material thinking

\footnotetext{
52 Patrick Connolly, 'Lockean Superaddition and Lockean Humility', Studies in History and Philosophy of Science 51 (2015), 53-61, at 53. In this section I ignore various distinctions (between natures and inner constitutions and real essences, between the natures of individuals and of kinds) that do not affect the point at issue.

53 The case of superaddition I am most concerned with is one that Locke says is possible, the superaddition of thought to the matter of human bodies. In writing to Stillingfleet, Locke seems to consider motion to be superadded to matter, as indeed are 'the properties of a rose, a peach, or an elephant' (Works 4: 460). On this view there is a good deal of known actual superaddition, not just possible superaddition, in the world. But see Stuart, Locke's Metaphysics, 266-7, on Locke's different uses of 'superaddition'.
} 
thing — come from. ${ }^{54}$ In the simplest version of this view, the answer, quite directly, is God. Thus this has been called a 'voluntarist' understanding of superaddition: the explanation lies in God's will. One might have a more complex version of this view that appeals to laws of nature, but that is itself, in this context, a roundabout way of talking about God's acts of will. ${ }^{55}$ On any version of this view, Locke's picture of the superaddition of thought to matter involves God giving certain material beings the power to think, and there being no way to explain the presence of that power of thought with reference only to the nature of the material beings, even their nature after the act of superaddition. ${ }^{56}$

On a non-voluntarist reading of superaddition, by contrast, the explanation for the presence of the superadded features lies in the nature of the thing to which the features are superadded. This can work in different ways: perhaps God, in superadding the features, merely arranges the parts of the thing appropriately, or perhaps he goes further and changes the nature of the thing. ${ }^{57}$ On this view, Locke's picture is that God might give the power of thought to some material beings by changing the inner nature of those material beings - not by simply adding the power of thought to their nature, but by making some other change, so that the nature of the

${ }^{54}$ For the view that superadded features do not so flow, see Margaret Dauler Wilson, Ideas and Mechanism (Princeton: Princeton University Press, 1999), 196-214. The view of Stuart (Locke's Metaphysics, 273) that Locke has no theory of how God might superadd thought to matter is related.

${ }^{55}$ For this sort of interpretation, emphasizing the role of laws of nature, see Edwin McCann, 'Locke's Philosophy of Body', in Vere Chappell (ed.), The Cambridge Companion to Locke (Cambridge: Cambridge University Press, 1994), 56-88.

${ }^{56}$ God's will is invoked as the cause of the power of thought, rather than the cause of individual thoughts, distinguishing this view from occasionalist ones. Michael Ayers, 'Mechanism, Superaddition, and the Proof of God's Existence in Locke's Essay', Philosophical Review 90 (1981), 210-51, alleges that Wilson's version of the voluntaristic view involves Locke in 'a curiously ambivalent attitude towards Occasionalism' (220), but Wilson justifiably denies this (Ideas and Mechanism, 211).

${ }^{57}$ For such views, see Ayers, Locke and Downing, 'Locke's Ontology'. 
changed beings now gives rise to and can fully explain, with no reference to God, the presence of the power of thought.

The views about perfection and causation Locke relied on in IV.x make a difference to which reading we choose here. In the case of the superaddition of thought to matter, the voluntarist reading of superaddition explains the presence of a perfection, thought, directly in terms of the actions of God. That does not violate Locke's views about the hierarchy and causation of perfections. The non-voluntarist reading, however, explains the presence of the superadded perfection in terms of the underlying, less perfect, features of the body, and that does appear to violate Locke's views about what can give rise to what. (The non-voluntarist reader of Locke thinks, after all, that once God has superadded thought to a material being, features of that material being - e.g., the arrangement of its particles - explain the presence of thought in it.) Strictly speaking, perhaps the non-voluntarist reading would not violate the principle about causation that is in play in IV.x.10, which is about diachronic efficient causation, as the superaddition case is plausibly an instance of synchronic grounding explanation. However, as we saw in looking at IV.x.16, Locke uses a similar principle in thinking about what is apparently a synchronic grounding explanation. That principle is apparently violated on the non-voluntarist reading of superaddition.

I think, then, that these thoughts about causation and perfection give us reason to favour a voluntarist reading of Locke on superaddition. This argument is not entirely decisive. At least two responses are possible.

One response is available to some, but not all, non-voluntarist readings. Consider in particular Lisa Downing's reading, on which what God does to an object's nature in superadding is not just to arrange corpuscles differently, but to give matter a different nature, a 
'nonmechanical real constitution'. ${ }^{58}$ (The new nature is not to include the power of thought itself, but is supposed to explain its presence.) Given that reading, perhaps one might say that this new nature is perfect enough to give rise to thought. But it is hard to see how Locke could say that. This new nature, whatever it is, is not thinking. Locke's views about the scale of perfection, however, are largely based on mental perfections, including the superiority of the thinking to the unthinking. Given this, the new nature would be less perfect than thought—and thus, by Locke's principles, unable to give rise to thought.

Another response is available both to Downing and to defenders of other non-voluntarist readings. They might say that God, in superadding thought to bodies by arranging their parts or changing their natures, is still the efficient cause of the presence of thought. If one could identify God as the cause in this case, then there would be no violation of Locke's views about perfection. Now, I suspect that Locke's comments about the causation of perfection are just not precise enough to determine whether God or the nature of the body is to be identified as the cause of the perfection, for the purpose of assessing whether the principle is violated. But I note that identifying God as the relevant cause in this case is liable to lead one to identifying God as the responsible cause of all change in the world, even in those cases in which one might want to say human beings were responsible. Moreover, one motivation for non-voluntarist readings has been to maintain the view that Locke thought all features of bodies could be explained in terms of their inner constitutions, flowing from their natures. ${ }^{59}$ Saying that God is the cause of a body's power of thought, while the body's nature is the explanation of that power, may not be contradictory, but is surely awkward. Thus, this response is not without its potential difficulties.

${ }^{58}$ Downing, 'Locke's Ontology', 372. Downing distinguishes two versions of that view, but the distinction is not relevant here.

${ }^{59}$ This is the sort of view that Ayers calls 'mechanism' (Locke, 2: 135-53) and Downing calls 'essentialism' ('Locke's Ontology', 368). 
Overall, then, though there is some room for response, it remains plausible that the nonvoluntarist reading of the superaddition of thought to matter commits Locke to a violation of his principles about the causation of perfections. One's reading of superaddition arguably ought not to commit Locke to that inconsistency. So there is reason to prefer a voluntarist reading of superaddition —one on which God would be the efficient cause and explanation of the presence of the superadded power of thought in material bodies, something that does not violate Locke's views about causation and perfection. ${ }^{60}$

\section{CONCLUSION}

Arguments about the causation of perfection play an important role in Essay IV.x. This reasoning about perfection might nevertheless seem odd as a piece of Lockean philosophy. Views about the possibilities of causation in a hierarchy of perfection are at home in the systems of Descartes and Cudworth. But how do they fit in Locke's book about the human understanding?

The observation that this reasoning is in some sense odd for Locke is appealing, but needs qualification. First, as I argued previously, Locke's belief in the hierarchy of perfection is not confined to IV.x, but seems to be a consistent view in the Essay. What is surprising in IV.x is the view about the causation of perfections. Secondly, I maintain that what Locke says about

${ }^{60}$ Connolly, 'Thinking Matter', has recently taken Essay IV.x to be compatible with what he calls 'reductionist understandings of superaddition' (129) - the views I called non-voluntarist readings, such as those of Ayers and Downing. I think, however, that something we agree onthe important role of principles of causation in Essay IV.x - shows this cannot be the case. Perhaps one might trace this disagreement to our earlier disagreement about whether to think about the causal principle in terms of perfections (note 37 above). Perhaps one can argue on, say, Downing's view, that the power of thought is already in the new nature of the material body, in some sense of 'in'. That new nature remains unthinking, however, and thus less perfect than the power of thought itself. 
thought in IV.x is consistent with what he says about superaddition in IV.iii. Although Locke's approach in IV.x may seem unusual for him, it is integrated in the larger work.

Those qualifications made, I am prepared to grant that the metaphysics of IV.x fits somewhat awkwardly with the rest of the Essay. Perhaps this is not a unique example though. Consider the much-discussed comments about substance at the start of Essay II.xxiii. There too Locke is discussing a metaphysical topic. There too his approach resembles one in an earlier Cambridge Platonist text—-though in that case one from More, rather than Cudworth. ${ }^{61}$ In both places one might conclude that Locke's metaphysical apparatus is somewhat under-developed. But in both cases Locke sees the need to address a metaphysical topic related to his main enquiry. ${ }^{62}$

Under-developed or not, Locke does rely on reasoning about the causation of perfections in Essay IV.x. He argues there that the first cause, the eternal being, cannot be material. It cannot be incogitative matter, and it cannot be cogitative matter. In arguing against the first option, and again in arguing against a version of the second option, Locke relies on arguments about the causation of perfections. Once we see that, we can also see something about how to understand the superaddition of thought to matter. In that area, we have reason to prefer a voluntarist

\footnotetext{
${ }^{61}$ I have in mind some passages early in The Immortality of the Soul: More's axiom VIII about unknown substance, the claim in the following chapter 3 that 'the notion of Spirit is altogether as intelligible as that of Body', and the associated discussions. Henry More, The Immortality of the Soul (London, 1659), 11-21.

${ }^{62}$ Stuart, Locke's Metaphysics finds there's a lot that's interesting to say about Locke's metaphysics, and Locke does make some metaphysical commitments in the Essay. Still there is a difference between Locke's approach and that of a more metaphysically focused contemporary such as Leibniz.
} 
reading. By doing so, we preserve the consistency of Locke's arguments in IV.x and IV.iii.6, a consistency which he himself emphasizes. ${ }^{63}$

${ }^{63}$ I thank audiences at Texas A\&M, the University of Florida, and the 2019 Eastern APA for discussion of these issues, and Patrick Connolly and Jessica Gordon-Roth for their comments on the APA paper. 